\title{
First report of Anastrepha obliqua (Macquart) and Ceratitis capitata(Wiedemann) (Diptera: Tephritidae) and the parasitoid Doryctobracon areolatus (Szépligeti) (Hymenoptera: Braconidae) in the oceanic archipelago of Fernando de Noronha, Brazil
}

\author{
Daniell Rodrigo Rodrigues Fernandes ${ }^{1 *}$ (D), Elton Lucio Araujo² (D), \\ Dayse Willkenia Almeida Marques $^{1}$ (D), Francisco Limeira-de-Oliveira ${ }^{3}$ (D), \\ José Albertino Rafael ${ }^{1}$
}

${ }^{1}$ Instituto Nacional de Pesquisas da Amazônia, Coordenação de Biodiversidade, Manaus, AM, Brasil.

${ }^{2}$ Universidade Federal Rural do Semi-Árido, Mossoró, RN, Brasil.

${ }^{3}$ Universidade Estadual do Maranhão, Centro de Estudos Superiores de Caxias, Caxias, MA, Brasil.

\section{A R T I C L E I N F O}

\section{Article history:}

Received 17 November 2021

Accepted 11 January 2022

Available online 04 February 2022

Associate Editor: Mariane Nickele

\begin{abstract}
A B S T R A C T
We recorded for the first time the presence of the two fruit flies pests, Anastrepha obliqua (Macquart) and Ceratitis capitata (Wiedemann) (Diptera: Tephritidae) and the parasitoid Doryctobracon areolatus (Szépligeti) (Hymenoptera: Braconidae) in the oceanic archipelago of Fernando de Noronha, Pernambuco, Brazil. The specimens were collected in traps installed during June/2019 to February/2020. The fruit flies and the parasitoid species are widespread in the Brazilian mainland and have most likely been introduced accidentally in the archipelago.
\end{abstract}

\section{Keywords:}

Fruit fly

Guava

Ichneumonoidea

Oceanic island

Neotropical region

The oceanic archipelago of Fernando de Noronha, state of Pernambuco, Brazil is located $360 \mathrm{~km}$ from the Brazilian continent and is a federal preservation area. The archipelago is entirely volcanic in origin and has never been connected to the continent. The total land area is $18.4 \mathrm{~km}^{2}$, of which $16.9 \mathrm{~km}^{2}$ is the main island of Fernando de Noronha (Lopes and Ulbrich, 2015).

The Fernando de Noronha archipelago (latitude $3^{\circ} 45^{\prime} \mathrm{S}$ to $3^{\circ} 57^{\prime} \mathrm{S}$; longitude $32^{\circ} 19^{\prime} \mathrm{W}$ to $32^{\circ} 41^{\prime} \mathrm{W}$ ) has a tropical oceanic climate (Awi Köppen classification). The temperature ranges from $24.9^{\circ} \mathrm{C}$ to $27.5^{\circ} \mathrm{C}$, with an annual mean of $26.2^{\circ} \mathrm{C}$ and annual precipitation of $1,292 \mathrm{~mm}$, but with large interannual variability (CLIMATE-DATA.ORG, 2021). The archipelago has a harsh environment, lacking a permanent source of freshwater, with low vegetation diversity and a shallow soil that has little capacity for water retention (Freitas et al., 2013; Rafael et al., 2020).

The flora of the Fernando de Noronha archipelago was basically approached by Ridley (1888) that reported several species of plants, however without quantifying them, and Batistella (1996) that carried out a floristic survey and cataloged 60 dominant plant species in

\footnotetext{
${ }^{*}$ Corresponding author.

E-mail: daniellrrfernandes@gmail.com (D.R.R. Fernandes).
}

the archipelago. Among the introduced species there are also some fruit trees, cultivated by the military (during military occupation in 1942) and that already reproduce naturally on the main island, such as cashews Anacardium occidentale L., mangoes Mangifera indica L., yellow mombin Spondias mombin L., red mombin Spondias purpurea (L.) (Anacardiaceae), sugar-apple Annona squamosa, soursop Annona muricata L. (Annonaceae), tamarinds Tamarindus indica (Fabaceae), guavas Psidium guajava L., cattley guava Psidium cattleyanum Sabine (Myrtaceae), avocados Persea americana Mill. (Lauraceae), star fruit Averrhoa carambola (Oxalidaceae), pitomba Talisia esculenta (Sapindaceae), coconut trees Cocos nucifera L. (Arecaceae), banana trees Musa spp. (Musaceae) and papayas Carica papaya L. (Caricaceae) (Guerriero, 2002; Teixeira et al., 2003; Serafini et al., 2010).

The entomofauna of this archipelago was listed, which currently comprises 454 species distributed in 21 orders of insects (Rafael et al., 2020). Recent studies have advanced in the knowledge of several orders, such as Diptera (Rafael et al., 2021a, 2021b), Embioptera (Costa-Pinto et al., 2021) and Hymenoptera (Fernandes et al., 2021).

Thus, the aim of this study was to identify the species of fruit flies (Tephritidae) and their possible parasitoid (Braconidae), collected in the oceanic archipelago of Fernando de Noronha, Brazil, during 
June/2019 to February/2020. Several sampling methods were used (with both, active and passive methods). Further details on the collection sites and methods can be found in Rafael et al. (2020; 2021b).

The specimens collected during this study was deposited in the following institutions: INPA, Instituto Nacional de Pesquisas da Amazônia, Manaus, Amazonas, Brazil (M.L. Oliveira, curator) and CZMA, Coleção Zoológica do Maranhão, Caxias, Maranhão, Brazil (F. Limeira-de-Oliveira, curator).

With the collections carried out, 90 specimens of two species of fruit flies were obtained, Anastrepha obliqua (Macquart) with 88 specimens (66 are females and 22 are males) and Ceratitis capitata(Wiedemann) with only two specimens. In the Boldró region, 10 females and 7 males of $A$. obliqua were collected with adapted McPhail traps (PET model trap and orange juice as attractant) and 52 females and 16 males, also with adapted McPhail traps (PET model trap and passion fruit juice as attractant); in the Sancho trail, one female and one male were collected with a Malaise trap, while in the Capim-Açu trail, only three females were collected, also with a Malaise trap. The two specimens of $C$. capitata, with only one female and one male were collected with a Shannon trap on the Sancho trail and, additionally, one female was photographed laying eggs in guava in the Boldró region (Figure 1).

Anastrepha comprises more than 300 species (Norrbom et al., 2018; Rodriguez and Norrbom, 2021) and 128 of them occur in Brazil mainland, and among them $A$. obliqua, which has already been reported in 26 Brazilian states infesting a total of 70 host species in different botanical families (Zucchi and Moraes, 2021a). Ceratitis capitata is an important worldwide pest in fruit crops, due its extensive human spread all over the world (Hernández-Ortiz et al., 2010). This species has already been reported in 25 Brazilian states infesting a total of 115 host species in 31 botanical families (Zucchi and Moraes, 2021b). Despite its wide geographical distribution, this is the first record of both species in the archipelago of Fernando de Noronha, Brazil.

Aside from fruit flies, the parasitoid Doryctobracon areolatus (Szépligeti) (Hymenoptera: Braconidae) was also collected in the present study. The specimens ( 3 females) were collected on the Capim-Açu trail with Malaise trap. In Brazil, this parasitoid is present in the 26 states
(Shimbori et al., 2021) and can parasitize both A. obliqua and C. capitata (Marinho et al., 2018).

It is uncertain whether these species have been brought to Fernando de Noronha by man or it was a natural dispersal. It is known that the island's fauna and flora has been greatly modified by anthropic action over the years, with intentional introductions of several species of fruits (Guerriero, 2002).

Additionally, there has been active commerce between the continent and Fernando de Noronha over the years, which most likely has facilitated the transport of both species as immatures (eggs, larvae or pupae) or as adults. It is possible that immatures were transported by ships or planes in fruits, or adult female specimens were trapped in one or both these means of transport. Cargo ships are not inspected to control the introduction of exotic species in Fernando de Noronha.

Another, less plausible hypothesis, is the possibility that these species have migrated naturally to the island. Alves et al. (2019) verified the presence of species of three orders of insects (Hemiptera, Lepidoptera and Odonata) collected attracted by light in a boat on the high sea about $389 \mathrm{~km}$ from the coast of Brazil. Due to the fact that the Fernando de Noronha archipelago is located about $360 \mathrm{~km}$ from the Brazilian coast, this possibility cannot be completely ruled out.

Thus, we think that the fruit flies species from Fernando de Noronha were probably imported by man and are now colonizing fruit farms on the main island and "Ilha da Rata". Our hypothesis is based on the fact that we found both the flies and the parasitoid, which leads us to believe that the accidental introduction most likely happened via fruit infested with flies and parasitoids.

It is important to emphasize that precautions must be taken regarding the entry of fruits from the mainland to the island (both by air and by sea). The introduction of new pests in this environment can generate economic impact on local crops, as well as increase the possibility of an even greater spread using the island as a source for new dispersions.

Therefore, further studies are needed, and continuous monitoring of these species is necessary to trace their route of introduction to the island, and also, to verify the possible impact of this pest on other fruit trees grown by local residents.

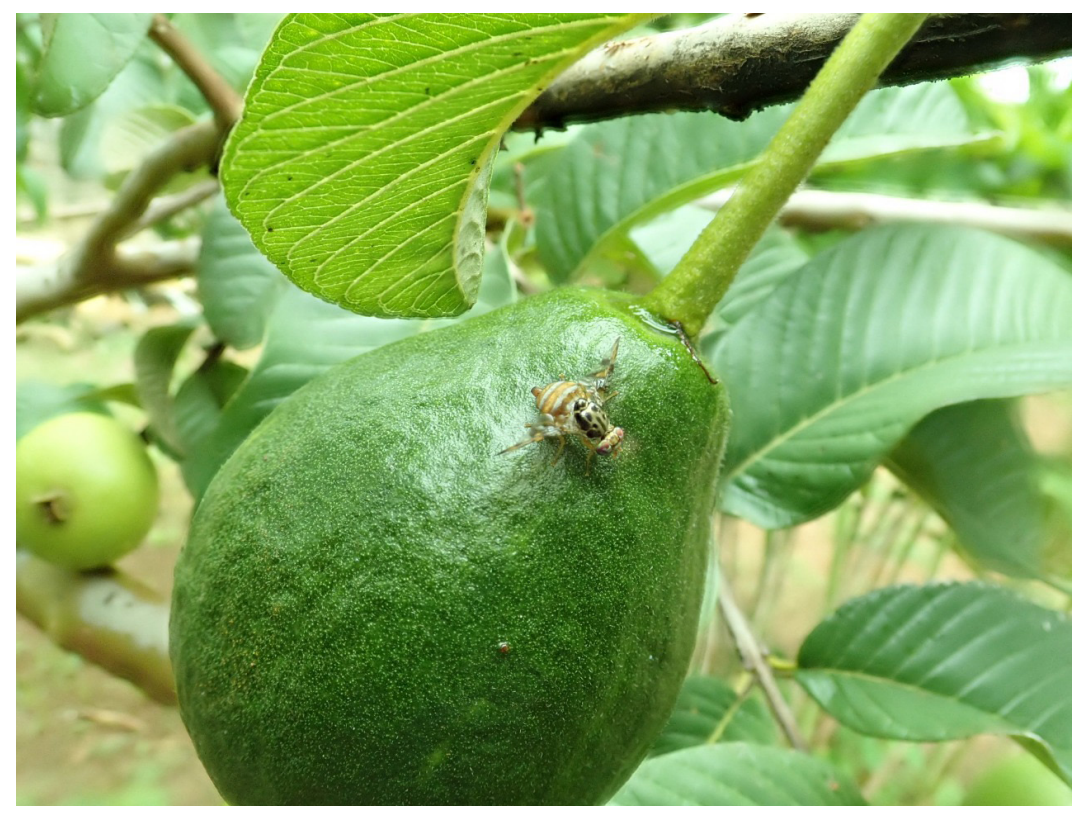

Figure 1 Female of Ceratitis capitata in guava fruit, in archipelago of Fernando de Noronha, Brazil, February 2020. 


\section{Acknowledgments}

We thank the Instituto Nacional de Pesquisas da Amazônia (INPA), for research support. To the Fundação de Amparo à Pesquisa do Estado do Amazonas (FAPEAM) and Conselho Nacional de Desenvolvimento Científico e Tecnológico (CNPq), for financial support Edital 001/2015 - CNPq/MCTI/FAPs/PROTAX (process number 440.423/2015-5) and for post-doctoral fellowship to D.W.A.M. To CNPq for a research grant through edital Universal 01/2016 - MCTI/CNPq (process number 405.630/2016-6) and for research fellowships to J.A.R. (process number 300019/2017-3), D.R.R.F.(PCI/CNPq, process no. 312879/2019-9) and E.L.A. (PQ/CNPq, process number 307193/2018-7). To Instituto Chico Mendes de Conservação da Biodiversidade (ICMBio) for the Collecting License number 62.821. To the staff of the Parque Nacional Marinho Fernando de Noronha, Ricardo Araújo, Viviane Vilella and Carolina Fonseca for administrative help. To the Autarquia Territorial do Distrito Estadual de Fernando de Noronha (ATDEFN), for the administrative facilities.

\section{Conflicts of interest}

The authors declare that they have no conflict of interest.

\section{Author contribution statement}

DRRF, ELA, DWAM, FLO and JAR Conceptualization-Equal, Investigationequal, Writing - original draft-Equal, Writing - review \& editing-Equal.

\section{References}

Alves, R.J.V., Costa, L.A.A., Soares, A., Silva, N.G., Pinto, Â.P., 2019. Open ocean nocturnal insect migration in the Brazilian South Atlantic with comments on flight endurance. PeerJ. 7, e7583. https://doi. org/10.7717/peerj.7583.

Batistella, M., 1996. Espécies vegetais dominantes do arquipélago de Fernando de Noronha: grupos ecológicos e repartição espacial. Acta Bot. Bras. 10 (2), 223-235. https://doi.org/10.1590/S010233061996000200003.

Climate-Data.org, 2021. Clima Fernando de Noronha (Brasil). Available in: https://pt.climate-data.org/america-do-sul/brasil/pernambuco/ fernando-de-noronha-1006098/ (accessed 30 December 2021).

Costa-Pinto, P.J., Olivier, R.S., Rafael, J.A., 2021. The first species of Embioptera (Insecta) from the archipelago of Fernando de Noronha (Pernambuco: brazil). Zootaxa. 4941 (1), 142-150. https://doi. org/10.11646/zootaxa.4941.1.9.

Fernandes, D.R.R., Rafael, J.A., Sobral, R., Santos, E.F., 2021. A new combination for Pompilus nesophilus Kirby, 1890 (Hymenoptera: Pompilidae): a forgotten spider wasp from archipelago of Fernando de Noronha (Pernambuco: Brazil). Zootaxa. 5047 (2), 197-200. https://doi.org/10.11646/zootaxa.5047.2.10.

Freitas, G.C.C., Brescovit, A.D., Vasconcelos, S.D., 2013. Spider diversity on the oceanic island of Fernando de Noronha, Brazil, and implications for species conservation. J. Insect Sci. 13 (148), 1-16. https://doi. org/10.1673/031.013.14801.

Guerriero, N., 2002. Ilhas oceânicas: Fernando de Noronha. Guerriero Edições, São Paulo, 96 pp.

Hernández-Ortiz, V., Guillén-Aguilar, J., López, L., 2010. Taxonomia e identificación de moscas de la fruta de importância económica em América. In: Montoya, P., Toledo, J., Hernández, E. (Eds.), Moscas de la fruta: fundamentos y procedimientos para su manejo. S y G Editores, México, pp. 49-80.
Lopes, R.P., Ulbrich, M.N.C., 2015. Geochemistry of the alkaline volcanicsubvolcanic rocks of the Fernando de Noronha Archipelago, southern Atlantic Ocean. Braz. J. Geol. 45 (2), 307-333. https://doi.org/10.15 90/23174889201500020009.

Marinho, C.F., Costa, V.A., Zucchi, R.A., 2018. Annotated checklist and illustrated key to braconid parasitoids (Hymenoptera, Braconidae) of economically important fruit flies (Diptera, Tephritidae) in Brazil. Zootaxa. 4527(1), 21-36. https://doi.org/10.11646/ zootaxa.4527.1.2

Norrbom, A.L., Barr, N.B., Kerr, P., Mengual, X., Nolazco, N., Rodriguez, E.J., Steck, G.J., Sutton, B.D., Uramoto, K., Zucchi, A., 2018. Synonymy of Toxotrypana Gerstaecker with Anastrepha Schiner (Diptera: tephritidae). Proc. Entomol. Soc. Wash. 4, 834-841. https://doi. org/10.4289/0013-8797.120.4.834.

Rafael, J.A., Limeira-de-Oliveira, F., Hutchings, R.W., Miranda, G.F.G., Silva Neto, A.M., Somavilla, A., Camargo, A., Asenjo, A., Pinto, Â.P., Bello, A.M., Dalmorra, C., Mello-Patiu, C.A., Carvalho, C.J.B., Takiya, D.M., Parizotto, D.R., Marques, D.W.A., Cavalheiro, D.O., Mendes, D.M. M., Zeppelini, D., Carneiro, E., Lima, É.F.B., Lima, E.C.A., Godoi, F.S.P., Pessoa, F.A.C., Vaz-de-Mello, F.Z., Sosa-Duque, F.J., Flores, H.F., Fernandes, I.O., Silva-Júnior, J.O., Gomes, L.R.P., Monné, M.L., Castro, M.C.M., Silva, M.P.G., Couri, M.S., Gottschalk, M.S., Soares, M.M.M., Monné, M.A., Rafael, M.S., Casagrande, M.M., Mielke, O.H.H., Grossi, P.C., Pinto, P.J.C., Bartholomay, P.R., Sobral, R., Heleodoro, R.A., Machado, R.J.P., Corrêa, R.C., Hutchings, R.S.G., Ale-Rocha, R., Santos, S.D., Lima, S.P., Mahlmann, T., Silva, V.C., Fernandes, D.R.R., 2020. Insect (Hexapoda) diversity in the oceanic archipelago of Fernando de Noronha, Brazil: updated taxonomic checklist and new records. Rev. Bras. Entomol. 64 (3), e20200052. https://doi. org/10.1590/1806-9665-rbent-2020-0052.

Rafael, J.A., Marques, D.W.A., Silva-Neto, A.M., Limeira-de-Oliveira, F., 2021a. Insect (Hexapoda) diversity in the oceanic archipelago of Fernando de Noronha, Brazil: Pipunculidae (Diptera). Entomol. Commun. 3, ec03008. https://doi.org/10.37486/2675-1305.ec03008.

Rafael, J.A., Marques, D.W.A., Silva-Neto, A.M., Limeira-de-Oliveira, F., 2021b. Insect (Hexapoda) diversity in the oceanic archipelago of Fernando de Noronha, Brazil: seasonality and populational density of Tabanidae (Diptera). Biota Neotrop. 21 (3), e20211211. https:// doi.org/10.1590/1676-0611-BN-2021-1211.

Serafini, T.Z., França, G.B., Andriguetto-Filho, J.M., 2010. Ilhas oceânicas brasileiras: biodiversidade conhecida e sua relação com o histórico de uso e ocupação humana. Rev. Ges. Cost. Integr. 10 (3), 281-301. https://doi.org/10.5894/rgci178.

Ridley, H.N., 1888. Notes on the botany of Fernando de Noronha. J. Linn. Societ 27, 1-95.

Rodriguez, P.A., Norrbom, A.L., 2021. New species and new records of Anastrepha (Diptera: Tephritidae) from Colombia. Zootaxa. 5004 (1), 107-130. https://doi.org/10.11646/zootaxa.5004.1.4.

Shimbori, E.M., Gadelha, S.S., Tavares, M.T., Fernandes, D.R.R., 2021. Braconidae. In Jardim Botânico do Rio de Janeiro. Catálogo Taxonômico da Fauna do Brasil. PNUD, Rio de Janeiro. Available in: http://fauna. jbrj.gov.br/fauna/faunadobrasil/14339. (accessed 20 December 2021).

Teixeira, W., Cordani, U.G., Menor, E.A., Teixeira, M.G., Linsker, R., 2003. Arquipélago Fernando de Noronha: o paraíso do vulcão. Terra Virgem, São Paulo, 167 pp.

Zucchi, R.A., Moraes, R.C.B., 2021a. Fruit Flies in Brazil - Anastrepha Species Their Host Plants And Parasitoids. Available in: http:// www.lea.esalq.usp.br/anastrepha. (accessed 17 November 2021).

Zucchi, R.A., Moraes, R.C.B., 2021b. Fruit Flies in Brazil - Hosts and Parasitoids of The Mediterranean Fruit Fly. Available in: http:// www.lea.esalq.usp.br/ceratitis. (accessed 17 November 2021). 